\title{
Intrageneric Relatedness of Listeria Pirie
}

\author{
SARAH E. STUART and H. J. WELSHIMER \\ Department of Microbiology, Medical College of Virginia, Health Sciences Division. Virginia Commonwealth \\ University, Richmond, Virginia 23298
}

\begin{abstract}
Deoxyribonucleic acid (DNA) base composition, differential biochemical properties, and DNA:DNA hybridization patterns of listeriae were studied. DNA from Listeria monocytogenes, $L$. grayi, and $L$. murrayi contained 38 to 40 mole percent guanine plus cytosine (\% GC); however, DNA from $L$. denitrificans contained $56 \%$ GC. Hybridization studies indicated that $L$. murrayi and $L$. gray $i$ were closely related and formed a homogeneous genetic group distinct from $L$. monocytogenes. L. monocytogenes strains could be separated into two groups on the basis of percent reassociation values with $L$. monocytogenes 19303 , the reference strain. One group of six strains showed 80 to $100 \%$ relative reassociation with strain 19303; four strains showed only 40 to $70 \%$ relative reassociation. There was no correlation between virulence, origin, or serotype and the degree of molecular relatedness to the reference strain. $L$. denitrificans was distinct from the other three species of Listeria in biochemical properties and DNA composition, and the relative reassociation values for DNA from $L$. denitrificans with DNA from other listeriae were very low. It is suggested that consideration be given to the reclassification of $L$. denitrificans.
\end{abstract}

Listeria monocytogenes (Murray et al.) Pirie was first described in 1926 (11) and until relatively recently was the only recognized species of the genus Listeria Pirie. Since 1961, three species, $L$. denitrificans Prévot (12), $L$. grayi Larsen and Seeliger (8), and L. murrayi Welshimer and Meredith (15), which to date appear apathogenic, have been added to the genus. Most studies have been related to the role of $L$. monocytogenes in infections, and although the isolation, identification, and immunological properties have been investigated, little comparative information concerning the physiology and metabolic characteristics of Listeria is available. The four species of Listeria bear a superficial, morphological resemblance to the Corynebacteriaceae, the family to which L. monocytogenes was assigned in the seventh edition of Bergey's Manual of Determinative Bacteriology (1). The inclusion of Listeria monocytogenes in the family Corynebacteriaceae warrants reexamination in view of numerical taxonomy studies based on Adansonian principles $(2,5,6)$. One species, $L$. denitrificans, is quite different from the other listeriae (12).

Our studies have been directed toward defining the intra- and intergeneric relatedness of strains which by present taxonomic criteria are classified as belonging to Listeria. As a prelude to examination of the taxonomic placement of the genus, a comparison of the four species of Listeria with respect to differential biochemical properties, deoxyribonucleic acid (DNA) composition and molecular relatedness as assessed by DNA:DNA duplex formation on nitrocellulose membrane filters was made.

\section{MATERIALS AND METHODS}

Bacterial strains, media, and biochemical tests. The bacterial strains used in this study are listed in Table 1. All listeriae were maintained on slants of Tryptose blood agar base (Difco) to which $1 \%$ glucose had been added. Tryptose-phosphate broth (TD, Tryptose [Difco], $20 \mathrm{~g} ; \mathrm{NaCl}, 10 \mathrm{~g}$; glucose, $2 \mathrm{~g} ; \mathrm{Na}_{2} \mathrm{HPO}_{4}, 3.5$ g; distilled water, 1 liter) was used to cultivate organisms for DNA extraction and for isotopic labeling. Escherichia coli CSH-2 was maintained on nutrient agar slants and grown in volume in tryptic soy broth (Difco).

The methods for biochemical characterization followed standard bacteriological techniques as presented in the Manual of Microbiological Methods (14).

DNA isolation. The method of Marmur (9) was used for all DNA extractions except strains of Listeria monocytogenes. Cells from $L$. monocytogenes strains were killed by heating at $70 \mathrm{C}$ for $10 \mathrm{~min}$ before centrifugation and then were suspended in $25 \mathrm{ml}$ of $0.005 \mathrm{M} \mathrm{CaCl}_{2}$ containing $100 \mu \mathrm{g}$ of lipase (type 448, 
TABLE 1. Bacterial strains ${ }^{a}$

\begin{tabular}{|c|c|c|}
\hline Strain & Origin & Source \\
\hline $\begin{array}{l}\text { Listeria monocytogenes } 19303 \\
\text { L. monocytogenes } \mathrm{A} 4413 \\
\text { L. monocytogenes } \mathrm{JC} \\
\text { L. monocytogenes } \mathrm{HBr} \\
\text { L. monocytogenes } \mathrm{HD} \\
\text { L. monocytogenes } \mathrm{T}_{3} \mathrm{~b} \\
\text { L. monocytogenes } \mathrm{T}_{4} \mathrm{~b} \\
\text { L. monocytogenes } \mathrm{V}-7 \\
\text { L. monocytogenes } \mathrm{V}-8 \\
\text { L. monocytogenes } \mathrm{V}-11 \\
\text { L. monocytogenes } \mathrm{V}-12 \\
\text { L. grayi ATCC } 19120 \\
\text { L. grayi } \mathrm{V}-1 \\
\text { L. murrayi } \mathrm{F}-2 \\
\text { L. murrayi } \mathrm{F}-6 \text { (ATCC } 25402 \text { ) } \\
\text { L. murrayi } \mathrm{F}-9 \text { (ATCC } 25401 \text { ) } \\
\text { L. murrayi } \mathrm{F}-11 \\
\text { L. murrayi } \mathrm{F}-12 \text { (ATCC } 25403 \text { ) } \\
\text { L. denitrificans ATCC } 14870 \\
\text { Escherichia coli CSH-2 }\end{array}$ & $\begin{array}{l}\text { Human } \\
\text { Human } \\
\text { Human } \\
\text { Human } \\
\text { Human } \\
\text { Human } \\
\text { Human } \\
\text { Vegetation } \\
\text { Vegetation } \\
\text { Vegetation } \\
\text { Vegetation } \\
\text { Chinchilla feces } \\
\text { Vegetation } \\
\text { Vegetation } \\
\text { Vegetation } \\
\text { Vegetation } \\
\text { Vegetation } \\
\text { Vegetation } \\
\text { Ox blood }\end{array}$ & $\begin{array}{l}\text { Ft. Detrick, Md. } \\
\text { Ft. Detrick, Md. } \\
\text { HJW } \\
\text { HJW } \\
\text { HJW } \\
\text { CDC (KC224) } \\
\text { CDC (KC226) } \\
\text { HJW } \\
\text { HJW } \\
\text { HJW } \\
\text { HJW } \\
\text { ATCC } \\
\text { HJW } \\
\text { HJW } \\
\text { HJW } \\
\text { HJW } \\
\text { HJW } \\
\text { HJW } \\
\text { ATCC } \\
\text { MCV }\end{array}$ \\
\hline
\end{tabular}

${ }^{a}$ Abbreviations: HJW, culture collection of H. J. Welshimer, Virginia Commonwealth Univ., Richmond, Va.; ATCC, American Type Culture Collection, Rockville, Md.; CDC, Center for Disease Control, Atlanta, Ga.; MCV, culture collection of the Department of Microbiology, Virginia Commonwealth Univ., Richmond, Va.

Nutritional Biochemical Co.) per $\mathrm{ml}$. The mixture was incubated with shaking for $1 \mathrm{~h}$ at $37 \mathrm{C}$, centrifuged, and suspended in saline-EDTA $(0.15 \mathrm{M}$ sodium chloride, $0.1 \mathrm{M}$ disodium ethylenediaminetetraacetate) with $800 \mu \mathrm{g}$ of lysozyme (A grade, Calbiochem) per ml. After incubation for $1 \mathrm{~h}$ at $37 \mathrm{C}, 100 \mu \mathrm{g}$ of Pronase (B grade, Calbiochem) per $\mathrm{ml}$ was added, and incubation continued for 1 to $3 \mathrm{~h}$. The remainder of the purification technique followed the procedure outlined by Marmur. DNA samples were stored in $1 \mathrm{X}$ SSC $(0.15 \mathrm{M}$ sodium chloride, $0.015 \mathrm{M}$ trisodium citrate) over chloroform at $4 \mathrm{C}$.

$T_{m}$ determination. The thermal melting point $\left(T_{m}\right)$ of DNA was determined in $0.1 \times$ SSC using a Gilford recording spectrophotometer (model 2400, Gilford Instrument Laboratories, Inc.) as described by Marmur and Doty (10). Mole percent guanine plus cytosine (\% GC) was calculated by using the following equation of Marmur and Doty (10): $\mathrm{GC}_{\mathbf{x}}=\mathrm{GC}_{\text {known }}+1 / 0.41$ $\left(T_{m_{x}}-T_{m_{\text {known }}}\right)$. DNA from $E$. coli $\mathrm{CSH}-2$ was used as the internal reference in each $T_{m}$ determination.

Buoyant density determination. The buoyant density of the DNA was determined by isopycnic centrifugation in $\mathrm{CsCl}$ at $25 \mathrm{C}$ in a Spinco model $\mathrm{E}$ analytical ultracentrifuge as described by Schildkraut et al. (13). Densitometer tracings of the ultraviolet films were made on a model 2400 Gilford recording spectrophotometer. The \% GC was calculated from the buoyant density according to DeLey (3): \% GC = $1038.47(\rho-1.6616)$. E. coli $\mathrm{CSH}-2$ was used as standard reference DNA. The buoyant density of the reference DNA was taken to be $1.710 \mathrm{~g} / \mathrm{cm}^{3}$ (13).

Preparation of radioactive DNA. Radioactive DNA was produced in $L$. monocytogenes 19303 and $L$. grayi ATCC 19120 by incubation with $\left[8-^{14} C\right.$ ] adenine as follows. A $0.1-\mathrm{ml}$ amount of a $24-\mathrm{h}$ TD broth culture was added to $500 \mathrm{ml}$ of TD broth and incubated without shaking for $17 \mathrm{~h}$ at room temperature $(23 \mathrm{C})$. Fresh medium $(100 \mathrm{ml})$ containing 200 $\mu \mathrm{Ci}$ of $\left[8-^{14} \mathrm{C}\right]$ adenine $(56 \mathrm{mCi} / \mathrm{mmol} ; 100 \mu \mathrm{Ci} / \mathrm{ml}$, Schwarz-Mann) was added, and stationary incubation continued for $3 \mathrm{~h}$. The cells were harvested by centrifugation and washed with saline-EDTA. DNA samples isolated from $L$. grayi ATCC 19120 and $L$. monocytogenes 19303 had specific activities ranging from 4,000 to 7,000 counts per min per $\mu \mathrm{g}$ of DNA.

Radioactive DNA from $L$. murray $i$ F-9 was obtained by incubation of log-phase cells grown in TD broth containing $100 \mu \mathrm{Ci}$ of $\left[8-^{14} \mathrm{C}\right]$ adenine $(50 \mathrm{mCi} / \mathrm{mmol}$; $100 \mu \mathrm{Ci} / \mathrm{ml}$, Schwarz-Mann) and $2 \times 10^{-4} \mathrm{M}$ deoxyguanosine. Label and deoxyguanosine were added simultaneously to a 12 -h shake culture, and incubation was continued at room temperature with shaking for $8 \mathrm{~h}$. The cells were harvested by centrifugation and washed in saline-EDTA. DNA isolated from $L$. murray $i$ F-9 had a specific activity of 3,600 counts per min per $\mu \mathrm{g}$ of DNA.

Labeled DNA was sheared by sonic treatment for 3 min using a Biosonik IV (Bronwill Scientific) set at 90 . To prevent thermal denaturation, the DNA sample was held in an ice bath and sonically treated for 10-s intervals $20 \mathrm{~s}$ apart.

Immobilization of DNA on filters. Approximately $50 \mu \mathrm{g}$ of unlabeled DNA dissolved in $3 \mathrm{ml}$ of $0.1 \times$ SSC were denatured by holding in a boiling-water bath for $10 \mathrm{~min}$. After immediate cooling in ice, an equal volume of $12 \times \mathrm{SSC}$ was added to give a final concentration of $6 \times$ SSC. A modification of the 
general procedure of Gillespie and Spiegelman (4) was used for immobilization of single-stranded DNA on nitrocellulose membrane filters (type B-6, $25 \mathrm{~mm}$, Schleicher and Schuell Co.). Immobilized DNA was prepared by gravity filtration of the denatured DNA in $6 \times$ SSC. The amount of DNA not retained by the membrane was calculated from the $A_{260}$ of the filtrate. The filters were allowed to air-dry overnight and then were heated for $8 \mathrm{~h}$ at $80 \mathrm{C}$. The loaded filters were stored in screw-capped scintillation vials at room temperature.

Hybridization and thermal elution. Filters loaded with 40 to $55 \mu \mathrm{g}$ of unlabeled, single-stranded DNA were placed individually in scintillation vials containing $1.5 \mathrm{ml}$ of $1.25 \times \mathrm{SSC}$ plus $0.02 \mathrm{M}$ tris (hydroxyme thyl)aminome thane-hydrochloride, $\mathrm{pH} 8$, and $1 \mathrm{\mu g}$ of sheared, denatured labeled DNA. Vials were incubated at $65 \mathrm{C}$ for $20 \mathrm{~h}$ without shaking. After incubation the filters were removed and washed in $10 \mathrm{ml}$ of $0.1 \times \mathrm{SSC}$ for $10 \mathrm{~min}$ at $55 \mathrm{C}$. Thermal elution profiles were obtained by washing the filters in $2.5 \mathrm{ml}$ of $0.1 \times \mathrm{SSC}$ for $15 \mathrm{~min}$ at $5 \mathrm{C}$ temperature increments from 60 to $85 \mathrm{C}$. Each aqueous sample and the filter were placed in $15 \mathrm{ml}$ of Triton X-100toluene base scintillation fluid $(666 \mathrm{ml}$ of toluene, 333 $\mathrm{ml}$ of Triton X-100, $5.5 \mathrm{~g}$ of 2,5-diphenyl-oxazol, and $0.125 \mathrm{~g}$ of 1,4-bis[2-,(4-methyl-5-phenyloxazolyl)benzene] and counted in a Packard Tri-Carb liquid scintillation spectrometer (model 3320, Packard Instrument Co.).

Thermal stability of hybrid duplexes was determined from thermal elution profiles. The mid-point of the thermal elution profile $\left(T_{m e}\right)$ is the temperature at which half of the reference DNA reassociated with test DNA bound to the filter has become dissociated and eluted into the wash solution. In each case, the $T_{m e}$ of the reference system matched the $T_{m}$ of native DNA from that organism. Percent base mispairing was calculated according to Laird et al. (7) from the change in $T_{m e}$ observed in hybrid test systems.

Relatedness was assessed by comparison of the relative counts per minute per microgram of labeled reference DNA bound by heterologous test DNA on filters to that bound by filters loaded with unlabeled test DNA from the same organism as the labeled reference DNA.

\section{RESULTS}

Biochemical differentiation of listeriae. The biochemical reactions which serve to distinguish between the four species of Listeria are given in Table 2.

Determination of base composition of DNA. The \% GC of DNA extracted from each species of Listeria calculated from both $T_{m}$ and buoyant density determinations are given in Table 3. Although the values for $\%$ GC calculated from buoyant density $(38-42)$ were somewhat higher than those calculated from $T_{m}$ (37-39), L. murrayi, L. grayi, and $L$. monocytogenes form a homogeneous group on the basis of DNA composition. DNA from $L$. denitrificans had a notably different composition $(56-57 \%$ GC).

DNA:DNA hybridizations. The results of DNA:DNA hybridizations using labeled $L$. monocytogenes 19303 DNA as reference are shown in Tables 4 and 5. L. monocytogenes strains $\mathrm{HD}, \mathrm{HBr}, \mathrm{JC}$, and $\mathrm{A} 4413$ showed a high degree of relatedness to $L$. monocytogenes 19303 (Table 4). These strains are all virulent isolants from human cases of listeriosis. Both $L$. monocytogenes $\mathrm{T}_{3} \mathrm{~b}$ and $\mathrm{T}_{4} \mathrm{~b}$ had fewer nucleotide sequences in common with strain 19303, and the duplexes formed were somewhat less stable. The L. monocytogenes strains designated $\mathrm{V}$ were isolated from vegetation in Hanover county, Va. L. monocytogenes V-7, a virulent isolant, appears to be identical to the reference strain. Strain V-12, also very closely related to 19303, is an avirulent isolant. The other two isolants, V-8 and V-11, had fewer nucleotide sequences in common with 19303; both strains are avirulent.

The molecular relatedness of the other species of Listeria to L. monocytogenes 19303 is shown in Table 5. L. grayi and L. murrayi were considerably less related to $L$. monocytogenes 19303 than were isolants identified as $L$. monocytogenes. $L$. denitrificans shared only $20 \%$ of its nucleotide sequences with $L$. monocytogenes 19303.

Table 6 shows the relative reassociation of labeled DNA from $L$. murrayi F-9, the type strain (15), with DNA from other listeriae. All strains of $L$. murrayi were closely related. Strains F-6 and F-11 gave consistently high percent reassociation values with $L$. murrayi F-9 with near perfect duplex formation; $L$. murrayi F-2 and F-12 exhibited fewer nucleotide sequences in common with the type strain. Strains F-2 and F-12 are distinguishable from other isolants identified as $L$. murrayi by their inability to produce acid from rhamnose. Hybrid duplexes formed between $L$. murrayi F-9 and L. grayi ATCC 19120 indicated $71 \%$ of the nucleotide sequences were shared by both species, although the duplexes were slightly less stable than those formed by the homologous system. V-1, to our knowledge the only other isolant of $L$. grayi, gave somewhat lower numerical value, but the duplexes were perfectly matched. The $L$. monocytogenes strains exhibited relative reassociation values with $L$. murrayi which ranged from 9 to $30 \%$, and the decreased thermal stabilities indicated considerable base mispairing. $L$. denitrificans was least related to $L$. murrayi F-9. 
TABLE 2. Differential properties of Listeria species ${ }^{a}$

\begin{tabular}{|c|c|c|c|c|c|c|}
\hline \multirow[b]{2}{*}{ Species } & \multicolumn{6}{|c|}{ Biochemical tests } \\
\hline & $\begin{array}{l}\text { Voges- } \\
\text { Proskauer }\end{array}$ & $\begin{array}{l}\text { Nitrate } \\
\text { reduction }\end{array}$ & $\begin{array}{l}\text { Acid from } \\
\text { mannitol }\end{array}$ & $\begin{array}{l}\text { Acid from } \\
\text { arabinose }\end{array}$ & $\begin{array}{l}\text { Acid from } \\
\text { xylose }\end{array}$ & $\begin{array}{l}\text { Metachromatic } \\
\text { granules }\end{array}$ \\
\hline $\begin{array}{l}\text { Listeria mono- } \\
\text { cytogenes }\end{array}$ & + & - & & & & \\
\hline L. grayi ......... & + & - & + & - & - & - \\
\hline L. denitrificans ..... & - & + & - & + & + & + \\
\hline L. murrayi $\ldots \ldots$ & + & + & + & - & - & - \\
\hline
\end{tabular}

${ }^{a}$ All listeriae are catalase positive, methyl-red positive, and produce acid from glucose, salicin, aesculin, and trehalose; these reactions serve to differentiate listeriae from other Corynebacteriaceae.

TABLE 3. DNA composition of listeriae

\begin{tabular}{|c|c|c|}
\hline \multirow[b]{2}{*}{ Strain } & \multicolumn{2}{|c|}{$\% \mathrm{GC}$} \\
\hline & From $T_{m}^{a}$ & $\begin{array}{c}\text { From buoyant } \\
\text { density }^{a}\end{array}$ \\
\hline 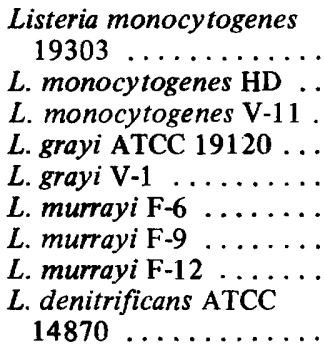 & $\begin{array}{l}38 \\
37 \\
37 \\
39 \\
39 \\
38 \\
38 \\
39 \\
56\end{array}$ & $\begin{array}{l}38 \\
39 \\
38 \\
41 \\
41 \\
42 \\
42 \\
42 \\
57\end{array}$ \\
\hline
\end{tabular}

$a$ The $\%$ GC values given are averages of at least three determinations using different DNA extractions.

Table 7 shows relative reassociation values for labeled DNA from $L$. grayi ATCC 19120 , the type strain (8), with DNA from other listeriae. As expected, L. grayi V-1 was most closely related to the type strain. L. murrayi strains showed relatively high reassociation values with only slight base mispairing. $L$. monocytogenes strains were much less related, and the hybrid duplexes formed were, in general, less well matched. Again, L. denitrificans was the least related to the reference strain.

Results of reciprocal binding reactions between $L$. monocytogenes 19303 and $L$. grayi ATCC 19120, L. monocytogenes 19303 and $L$. murrayi F-9, and $L$. grayi ATCC 19120 and $L$. murrayi F-9 were nearly identical in thermal stability; however, nonreciprocal binding appeared to occur in reactions between $L$. murrayi F-9 and L. monocytogenes 19303 and $L$. grayi ATCC 19120 and $L$. monocytogenes 19303. L. grayi ATCC 19120 showed 9\% less binding to $L$. monocytogenes 19303 than the reciprocal reaction, and $L$. monocytogenes 19303 showed 5\% less reassociation with $L$. murrayi F-9 than the reciprocal reaction. $L$. grayi ATCC 19120 bound only $2 \%$ less to $L$. murrayi than the reciprocal case. These apparent differences may reflect inherent differences in purity of certain of the DNA preparations used for hybridization, unknown differences in experimental method, or a difference in genome size of these organisms. Genome size determinations have not yet been made.

\section{DISCUSSION}

With the exception of $L$. denitrificans, listeriae form a homogeneous group with respect to composition of DNA. L. denitrificans also differs from the other listeriae in numerous taxonomically important reactions. It is the only species of Listeria which produces acid from xylose and arabinose and does not produce acetylmethylcarbinol. Furthermore, $L$. denitrificans is the sole member of the genus to produce metachromatic granules, accumulate fat droplets, and give a positive benzidine test.

Based on hybridization studies, L. monocytogenes strains may be separated into two easily distinguishable groups (Table 8 ). $L$. monocytogenes strains $\mathrm{HD}, \mathrm{HBr}, \mathrm{JC}, \mathrm{A} 4413$, $\mathrm{V}-7$, and $\mathrm{V}-12$ that comprise the first group are all closely related to Listeria monocytogenes 19303, although they represent both virulent and avirulent strains of diverse origin and serotype. These strains form a compact group which exhibits little relatedness to either $L$. murrayi or L. grayi. L. monocytogenes strains in the second group, $T_{3} b, T_{4} b, V-8$, and $V-11$, exhibited lower reassociation values with $L$. monocytogenes 19303, ranging from 40 to $70 \%$. The degree of relatedness of these strains 
TABLE 4. Molecular relatedness of Listeria monocytogenes strains

\begin{tabular}{|c|c|c|c|}
\hline $\begin{array}{c}\text { Source of } \\
\text { unlabeled DNA }\end{array}$ & $\begin{array}{c}\text { Relative reassociation } \\
\text { with } L \text {. monocytogenes } 19303 \\
(\%)\end{array}$ & $\Delta T_{\boldsymbol{m} \boldsymbol{e}^{a}}^{a}$ & $\underset{\text { mispairing }}{\text { Base }}$ \\
\hline 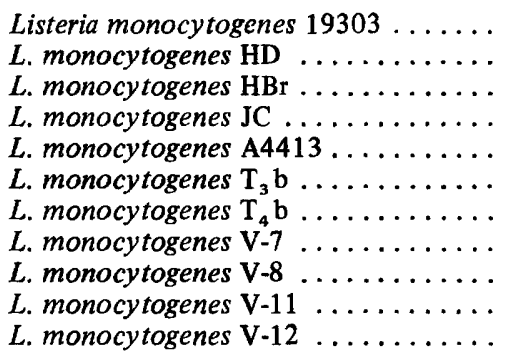 & $\begin{array}{r}100 \\
90 \\
90 \\
85 \\
82 \\
40 \\
69 \\
100 \\
60 \\
59 \\
97\end{array}$ & $\begin{array}{l}0 \\
0 \\
0 \\
2 \\
0 \\
2 \\
2 \\
1 \\
0 \\
0 \\
2\end{array}$ & $\begin{array}{l}0 \\
0 \\
0 \\
3 \\
0 \\
3 \\
3 \\
1.5 \\
0 \\
0 \\
3\end{array}$ \\
\hline
\end{tabular}

${ }^{a}$ Difference in degrees $\mathrm{C}$ between the $T_{m e}$ of the reference system and the $T_{m e}$ of the test system.

${ }^{b}$ Calculated according to Laird (7); $1.5 \%$ bases mispaired per degree $\mathrm{C} \Delta T_{m e}$.

TABLE 5. Molecular relatedness of Listeria monocytogenes 19303 to other listeriae

\begin{tabular}{|c|c|c|c|}
\hline $\begin{array}{c}\text { Source of } \\
\text { unlabeled DNA }\end{array}$ & $\begin{array}{c}\text { Relative reassociation } \\
\text { with } L \text {. monocytogenes } 19303 \\
(\%)\end{array}$ & $\Delta T_{m e}^{a}$ & $\underset{(\%)}{\text { mispairing }^{b}}$ \\
\hline 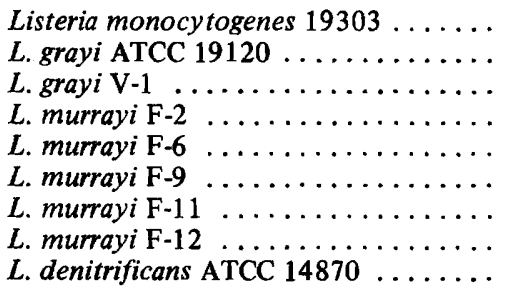 & $\begin{array}{r}100 \\
21 \\
40 \\
44 \\
25 \\
20 \\
33 \\
36 \\
20\end{array}$ & $\begin{array}{l}0 \\
2 \\
1 \\
2 \\
2 \\
3 \\
3 \\
2 \\
2\end{array}$ & $\begin{array}{l}0 \\
3 \\
1.5 \\
3 \\
3 \\
4.5 \\
4.5 \\
3 \\
3\end{array}$ \\
\hline
\end{tabular}

${ }^{a}$ See Table 4.

${ }^{b}$ See Table 4.

TABLE 6. Relative reassociation of Listeria murrayi F-9 DNA with DNA from other listeriae

\begin{tabular}{|c|c|c|c|}
\hline $\begin{array}{c}\text { Source of } \\
\text { unlabeled DNA }\end{array}$ & $\begin{array}{l}\text { Relative binding } \\
\text { with } L . \text { murrayi F-9 } \\
(\%)\end{array}$ & $\Delta T_{m e}^{a}$ & $\underset{(\%)}{\text { Base }} \underset{\text { mispairing }}{b}$ \\
\hline 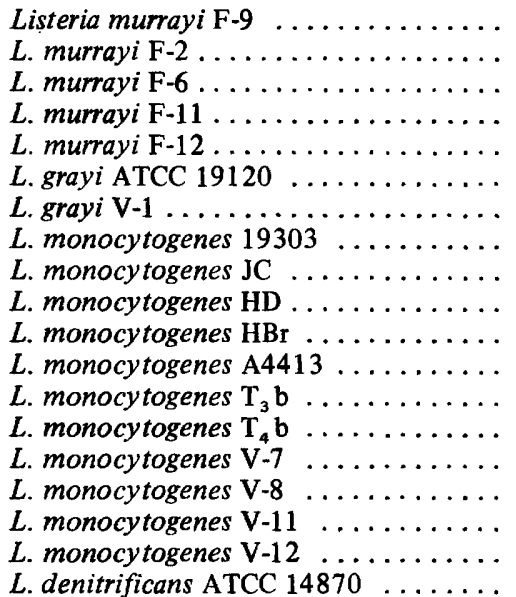 & $\begin{array}{r}100 \\
82 \\
99 \\
96 \\
71 \\
71 \\
61 \\
25 \\
16 \\
9 \\
11 \\
14 \\
12 \\
17 \\
14 \\
30 \\
12 \\
15 \\
8\end{array}$ & $\begin{array}{l}0 \\
2 \\
0 \\
1 \\
0 \\
0 \\
0 \\
3 \\
2 \\
6 \\
3 \\
2 \\
3 \\
2 \\
3 \\
3 \\
2 \\
2 \\
1\end{array}$ & $\begin{array}{l}0 \\
3 \\
0 \\
1.5 \\
0 \\
0 \\
0 \\
4.5 \\
3 \\
9 \\
4.5 \\
3 \\
4.5 \\
3 \\
4.5 \\
4.5 \\
3 \\
3 \\
1.5\end{array}$ \\
\hline
\end{tabular}

${ }^{a}$ See Table 4.

$b$ See Table 4. 
TABLE 7. Relative reassociation of Listeria grayi ATCC 19120 DNA with DNA from other listeriae

\begin{tabular}{|c|c|c|c|}
\hline $\begin{array}{c}\text { Source of } \\
\text { unlabeled DNA }\end{array}$ & $\begin{array}{c}\text { Relative binding } \\
\text { to L. grayi ATCC } 19120 \\
(\%)\end{array}$ & $\Delta T_{m e}^{a}$ & $\begin{array}{c}\text { Base } \\
\text { mispairing } \\
(\%)\end{array}$ \\
\hline Listeria grayi ATCC $19120 \ldots \ldots \ldots$ & 100 & 0 & 0 \\
\hline L. grayi $\mathrm{V}-1 \ldots \ldots \ldots \ldots \ldots \ldots$ & 84 & 2 & 3 \\
\hline L. murrayi $\mathrm{F}-2 \ldots \ldots \ldots \ldots \ldots$ & 58 & 1.4 & 2.1 \\
\hline L. murrayi $\mathrm{F}-6 \ldots \ldots \ldots \ldots \ldots$ & 68 & 1 & 1.5 \\
\hline L. murrayi F-99 . . . . . . . . & 69 & 2.5 & 3.7 \\
\hline L. murrayi $\mathrm{F}-11 \ldots \ldots \ldots \ldots$ & 76 & 6 & 8.5 \\
\hline L. murrayi $\mathrm{F}-12 \ldots \ldots \ldots \ldots \ldots$ & 75 & 1 & 1.5 \\
\hline L. monocytogenes $19303 \ldots \ldots \ldots$. . & 12 & 0.4 & 0.6 \\
\hline L. monocytogenes $\mathrm{T}_{3} \mathrm{~b} \ldots \ldots$ & 10 & 2 & 3 \\
\hline L. monocytogenes $\mathrm{T}_{4} \mathrm{~b} \ldots$ & 12 & 0.4 & 0.6 \\
\hline L. monocytogenes $\mathrm{HD}$. . . & 13 & 3 & 4.5 \\
\hline L. monocytogenes $\mathrm{HBr} \ldots$. & 13 & 3 & 4.5 \\
\hline L. monocytogenes A4413 . . & 18 & 7 & 10.0 \\
\hline L. monocytogenes JC . . . . . . & 13 & 3 & 4.5 \\
\hline L. monocytogenes $\mathrm{V}-7 \ldots$ & 10 & 2 & 3 \\
\hline L. monocytogenes V-8 . . & 7 & 2 & 3 \\
\hline L. monocytogenes $\mathrm{V}-11 \ldots$ & 10 & 4 & 6 \\
\hline L. monocytogenes $\mathrm{V}-12 \ldots \ldots \ldots$ & 9 & 0 & 0 \\
\hline L. denitrificans ATCC $14870 \ldots \ldots \ldots$ & 5 & 4 & 6 \\
\hline
\end{tabular}

${ }^{a}$ See Table 4.

$b$ See Table 4.

TABLE 8. Intrageneric relatedness of listeriae

\begin{tabular}{|c|c|c|c|}
\hline $\begin{array}{c}\text { Source of } \\
\text { unlabeled DNA }\end{array}$ & $\begin{array}{l}\text { Relative binding } \\
\text { to } L . \text { monocytogenes } \\
19303(\%)\end{array}$ & $\begin{array}{l}\text { Relative binding } \\
\text { to } L . \text { murrayi F-9 } \\
(\%)\end{array}$ & $\begin{array}{c}\text { Relative binding } \\
\text { to L. grayi ATCC } \\
19120(\%)\end{array}$ \\
\hline $\begin{array}{l}\text { Listeria monocytogenes group I } \\
\quad(19303, \mathrm{HD}, \mathrm{HBr}, \mathrm{JC}, \mathrm{A} 4413, \\
\text { V-7, V-12) } \ldots \ldots \ldots \ldots \ldots \ldots \\
\text { L. monocytogenes group II }(\mathrm{V}-11, \ldots \ldots \\
\quad \mathrm{V}-8, \mathrm{~T}_{3} \mathrm{~b}, \mathrm{~T}_{4} \text { b) } \ldots \ldots \ldots \ldots \ldots \ldots \\
\text { L. grayi }(\mathrm{ATCC} 19120, \mathrm{~V}-1) \ldots \ldots \ldots \ldots \\
\text { L. murrayi }(\mathrm{F}-2, \mathrm{~F}-6, \mathrm{~F}-9, \\
\quad \mathrm{F}-11, \mathrm{~F}-12) \ldots \ldots \ldots \\
\text { L. denitrificans ATCC } 14870 \ldots \ldots \ldots\end{array}$ & $\begin{array}{r}80-100 \\
40-70 \\
21,40 \\
\\
20-44 \\
20\end{array}$ & $\begin{array}{r}10-25 \\
\\
12-30 \\
71,61 \\
71-100 \\
8\end{array}$ & $\begin{array}{r}9-18 \\
10-15 \\
100,84 \\
58-76 \\
5\end{array}$ \\
\hline
\end{tabular}

to L. murrayi and L. grayi, however, is similar to that of the first group.

The two strains of $L$. grayi showed relatively high and comparable degrees of relatedness to L. murrayi F-9 but far fewer nucleotide sequences in common with $L$. monocytogenes. L. gray $i$ is distinguished from $L$. murrayi only by its ability to reduce nitrate (Table 2 ). The ability to produce acid from mannitol is shared by both of these species and differentiates them from $L$. monocytogenes. Both $L$. grayi and $L$. murrayi lack $\mathrm{H}$ factors in common with $L$. monocytogenes $(8,15)$. Although the serotypes of $L$. grayi and $L$. murrayi have not yet been fully elucidated, some flagellar antigens are shared (15).
The L. murrayi strains showed 20 to $40 \%$ relative reassociation with $L$. monocytogenes 19303 and 71 to $100 \%$ relative reassociation with $L$. murray $i$ F-9. The strains more closely related to $L$. monocytogenes had fewer nucleotide sequences in common with $L$. murrayi.

Reassociation values for DNA from the sole strain of Listeria denitrificans studied with any of the other species of Listeria were quite low.

These studies indicate that the two avirulent species, $L$. murrayi and $L$. grayi, are quite closely related. Further, our hybridization results suggest that $L$. murrayi and $L$. grayi comprise a homogeneous genetic group distinct from $L$. monocytogenes. Although there is no notable demarkation in the classical taxonomic 
sense, L. monocytogenes strains fall into two distinct groups: those closely related to the reference strain 19303 and those which showed only 40 to $70 \%$ relative reassociation. In some $L$. monocytogenes strains, as much as $60 \%$ of the DNA has diverged to a point where it no longer reassociates with the reference strain under stringent conditions. There is no apparent correlation between the source of isolation, serotype, or virulence of these strains and their molecular relatedness.

On the basis of differences in taxonomically important biochemical reactions, growth characteristics, DNA base composition, and low molecular relatedness to any of the other species of Listeria, strong consideration should be given to reclassification of $L$. denitrificans.

\section{ACKNOWLEDGMENTS}

This investigation was supported by A.D. Williams Institutional Research Support Funds, Medical College of Virginia, Health Sciences Division, Virginia Commonwealth University. One of us (S.E.S.) was supported by National Defense Education Administration Title IV Fellowship 437-003725.

We wish to thank S. Gaylen Bradley for his advice on hybridization methodology and James D. Punch for invaluable assistance in specific isotopic labeling.

Address requests for reprints to: Dr. H. J. Welshimer, Department of Microbiology, Medical College of Virginia, Virginia Commonwealth University, Richmond, Va. 23298.

\section{LITERATURE CITED}

1. Breed, R. S., E. G. D. Murray, and N. R. Smith (ed.). 1957. Bergey's manual of determinative bacteriology. 7th ed., p. 597-599. The Williams and Wilkins Co., Baltimore.

2. Davis, G. H., L. Fomin, E. Wilson, and K. G. Newton. 1969. Numerical taxonomy of Listeria, streptococci and possibly related bacteria. J. Gen. Microbiol. 57:333-348.

3. DeLey, J. 1970. Reexamination of the association between melting point, buoyant density, and chemical base composition of deoxyribonucleic acid. J. Bacteriol. 101:738-754.

4. Gillespie, D., and S. Spiegelman. 1965. A quantitative assay for DNA-RNA hybrids with DNA immobilized on a membrane. J. Mol. Biol. 12:829-842.

5. Jones, D., and P. H. A. Sneath. 1970. Genetic transfer and bacterial taxonomy. Bacteriol. Rev. 34: 40-81.

6. Jones, D., P. H. A. Sneath, and M. Woodbine. 1966. The relation between Listeria and other bacteria, p. 161-164. In Proceedings of the Third International Symposium on Listeriosis, Bilthoven, Holland.

7. Laird, C. D., B. L. McConaughy, and B. J. McCarthy. 1969. Rate of fixation of nucleotide substitutions in evolution. Nature (London) 224: 149-154.

8. Larsen, H. E., and H. P. R. Seeliger. 1966. A mannitol fermenting Listeria: Listeria grayi sp. n., p. 35-39. In Proceedings of the Third International Symposium on Listeriosis, Bilthoven, Holland.

9. Marmur, J. 1961. A procedure for the isolation of deoxyribonucleic acid from microorganisms. J. Mol. Biol. 3:201-218.

10. Marmur, J., and P. Doty. 1962. Determination of the base composition of deoxyribonucleic acid from its thermal denaturation temperature. J. Mol. Biol. 5:109-118.

11. Murray, E. G. D., R. A. Webb, and M. B. R. Swann. 1926. A disease of rabbits characterized by large mononuclear leukocytosis, caused by a hitherto undescribed bacillus: Bacterium monocytogenes (n. sp.). J. Pathol. Bacteriol. 29:407-439.

12. Prévot, A. 1961. Traité de systématique bactérienne, p. 512. Dunod, Paris.

13. Schildkraut, C. L., J. Marmur, and P. Doty. 1962. Determination of the base composition of deoxyribonucleic acid from its buoyant density in CsCl. J. Mol. Biol. 4:430-443.

14. Society of American Bacteriologists. 1957. Manual of microbiological methods. McGraw-Hill Book Co., New York.

15. Welshimer, H. J., and A. L. Meredith. 1971. Listeria murrayi sp. n.: a nitrate reducing mannitol fermenting Listeria. Int. J. Syst. Bacteriol. 21:3-7. 